\section{Occupational asthma in a coal miner}

\author{
Pedro M Gamboa, Ignacio Jáuregui, Iñaki \\ Urrutia, Ignacio Antépara, Genoveva \\ González, Victoria Múgica
}

\begin{abstract}
Occupational asthma in coal miners is hardly recognised. A report is presented of a coal miner whose clinical picture suggested a respiratory allergy which occurred only in the mine where he worked. Serum specific IgE levels, skin tests, and bronchial provocation tests with different commercial extracts showed sensitisation to Rhizopus nigricans. Rhizopus spp were found inside the mine, as demonstrated by cultures on petri plates.

(Thorax 1996;51:867-868)
\end{abstract}

Keywords: allergens, asthma, bronchial provocation tests, fungi, occupational disease, Rhizopus.

Coal miners are known to suffer from various respiratory disorders including chronic bronchitis and pneumoconiosis. Description of occupational asthma in coal miners has been limited to a single report of asthma due to diisocyanates employed in coal mines. ${ }^{1}$ We report the case of a coal miner whose presentation suggested occupational asthma.

\section{Case report}

A 30 year old man who had worked as an underground coal miner for 12 years presented to the outpatient department because of a one year history of rhinorrhoea, sneezing, cough, and wheezing which was only present at work. These symptoms began within three hours of arrival at the mine and disappeared after leaving his workplace and/or following the inhalation of a $\beta_{2}$ agonist. He later developed a progressive increase in the number and duration of these episodes, requiring at least one week off work to become asymptomatic again.

The patient had no previous clinical history. He had never smoked and had no hobbies that could be related to his symptoms. Physical examination on admission, after three weeks away from work, was normal. The blood count, erythrocyte sedimentation rate, and biochemistry were normal as were chest radiographs and spirometric parameters. The serum IgE level was $191 \mathrm{kU} / \mathrm{l}$. Skin prick tests carried out with common allergens such as domestic and storage mites, grass, trees and weed pollens, animal danders, and common moulds gave negative results. Intradermal tests were subsequently performed with commercial extracts from common moulds such as Alternaria alternata, Cladosporium herbarum, Aspergillus fumigatus, Penicillium spp, Pullularia pululans, Mucor racemosus, and Rhizopus nigricans with positive results for Rhizopus nigricans only $(25 \times 20$ $\mathrm{mm}$, histamine control $10 \times 10 \mathrm{~mm})$. Rhizopus was prick tested again with a different commercial extract and a positive result was also obtained $(15 \times 20 \mathrm{~mm}$, histamine control $6 \times 6$ $\mathrm{mm})$. Ten atopic control patients were prick tested with the same extracts with negative results.

Serum specific IgE against Rhizopus nigricans (Phadezym RAST) was $3.50 \mathrm{PRU} / \mathrm{ml}$ (class 2). No serum specific IgE against other allergens was detectable.

\section{MOULD IDENTIFICATION}

The patient worked in an old coal mine without steam, gas, or electrical machinery; a system based on compressed air was used for removing dust and debris to the surface. Rock galleries were consolidated by wooden coating made of untreated pine so the patient was not exposed to any source of isocyanates or synthetic resins. The mine was extraordinarily humid and working on watery soil was common. Mould colonies were extensive all over the mine walls, even forming cobwebs on the crossheads of the galleries.

Twelve petri plates containing an agarSabouraud culture medium were placed one metre above the soil inside the mine for 24 hours. Samples of visible fungi from the crossheads were also cultured. Subsequent identification by light microscopy showed abundant colonies of the following genera: Cladosporium, Aspergillus, Penicillium, Pullularia, Rhodotorula, and Rhizopus.

\section{BRONCHIAL PROVOCATION TESTS}

The patient was away from work for three months before the provocation test was performed. He was free of symptoms during the last two months, off medication, and with normal spirometric values.

An abbreviated bronchial challenge test with methacholine ${ }^{2}$ was first carried out with positive results. Two bronchial challenge tests were then performed with different extracts in weight/volume from Rhizopus nigricans (Alergia e Inmunología Abelló SA, Spain, and Dome-Hollister/Stier, USA, respectively), ${ }^{3}$ with an immediate and reproducible response (table 1). A follow up test with a mini-Wright peak flow meter failed to reveal late asthmatic responses during the 24 hours after either of the challenges. Two asthmatic volunteers who were allergic to mites were provoked with the 
Table 1 Bronchial provocation tests with two different commercial extracts from Rhizopus nigricans

\begin{tabular}{lll}
\hline Functional parameters & Baseline & 20 minutes after challenge \\
\hline Extract 1 (Alergia e Inmunologia Abello & & \\
SA, Madrid, Spain) & \\
FEV $_{1}$ & $3.740(93 \%)$ & $2.990(-20 \%)$ \\
FVC & $4.580(91 \%)$ & $3.770(-17 \%)$ \\
PEF & $7.810(80 \%)$ & $6.360(-19 \%)$ \\
MEF $_{50}$ & $3.610(85 \%)$ & $2.640(-27 \%)$ \\
Extract 2 (Dome-Hollister/Stier, USA) & $3.830(95 \%)$ & $3.000(-21 \%)$ \\
FEV $_{1}$ & $4.620(91 \%)$ & $4.200(-10 \%)$ \\
FVC & $7.810(80 \%)$ & $4.900(-37 \%)$ \\
PEF $_{\text {MEF }}$ & $3.920(93 \%)$ & $3.300(-16 \%)$ \\
\hline
\end{tabular}

$\mathrm{FEV}_{1}=$ forced expiratory volume in one second; $\mathrm{FVC}=$ forced vital capacity; $\mathrm{PEF}=$ peak expiratory flow; MEF = mid expiratory flow.

same extracts, with negative results. The patient was rechallenged with a standardised extract from Alternaria alternata some days later without response.

An occupational disease was recognised and since then the patient has kept away from the mine. He has been asymptomatic for two years, off medication, and with normal spirometric values. No additional methacholine tests have been performed.

\section{Discussion}

Rhizopus nigricans has been reported to be responsible for occupational respiratory disease, ${ }^{4}$ mainly in hypersensitivity pneumonitis such as malt worker's lung ${ }^{5}$ and wood trimmer's disease. ${ }^{6}$ It has also been implied as an allergen in the pathogenesis of bronchial asthma. $^{7}$

Our studies were directed towards the eventual diagnosis of occupational asthma. Bronchial hyperresponsiveness was demonstrated and allergy studies showed sensitisation to Rhizopus nigricans with concomitant results in skin tests and serum specific IgE. The flora on airborne fungi inside the mine was then studied and Rhizopus nigricans was found. Thereafter, sensitisation to the mould was assessed by allergen-specific bronchial provocation tests.
One of the major difficulties in the diagnosis of allergy to airborne fungi is obtaining allergenic extracts with enough potency and numbers of allergens. ${ }^{8}$ Thus, two consecutive specific bronchial provocation tests were performed with two different commercial allergenic extracts and were positive in both cases (table 1). A control challenge test with Alternaria, which was also present in the mine, was negative, thus confirming the specificity of a mono-sensitisation to Rhizopus nigricans.

The only existing report on bronchial asthma related to coal mining concerns the diisocyanates employed for rock consolidation in Belgian coal mines ${ }^{1}$ where asthma from diisocyanates is accepted as an occupational disease for compensation. Our patient, however, was unexposed to any source of suspicious chemicals. He was the only worker to be affected among 120 miners, 60 of whom worked below the surface. After two years no special measures have been taken to limit the inner dampness and growth of fungi.

The authors gratefully acknowledge Dr C Pérez-Santos from the Allergy Division of Bayer SA, Madrid, Spain, for his help in mould identification.

1 Nemery B, Lenaerts L. Exposure to methylene diphenyl diisocyanate in coal mines. Lancet 1993;341:318.

2 Chatham M, Bleecker ER, Norman P, Smith PL, Mason P. A screening test for airways reactivity: an abbreviated methacholine inhalation challenge. Chest 1982; 82:15-8.

3 Cropp GJ, Bernstein IL, Boushey HS, Hyde RV, Rosenthal RR, Spector SL, et al. Guidelines for bronchial inhalation challenges with pharmacologic and antigenic agents. ATS News 1980;6:11-19.

4 Gravesen S. Rhizopus. In: Wilken-Jensen W, Gravesen S, eds. Atlas of moulds in Europe causing respiratory allergy. Copenhagen:ASK, 1984:40-1.

5 Kurup VP, Barboriak JJ, Fink JN. Hypersensitivity pneumonitis. In: Al-Doory Y, Domson JF, eds. Mould allergy. Philadelphia:Lea \& Febiger, 1984:216-43.

6 Belin L. Health problems caused by actinomycetes and moulds in the industrial environment. Allergy 1985; 4(Suppl 3):24-9.

7 Solomon WR. Aerobiology and inhalant allergens. I. Pollens and fungi. In: Middleton Jr E, et al, eds. Allergy. Principles and practice. 3rd edn. St Louis:Mosby, 1988:312-58.

8 Ginarsson R, Aukrust L. Allergens of the fungi imperfecti. Clin Rev Allergy 1992;10:165-90. 